\title{
ExILE OR OpPoRTUNITY? The Benefits of Mastering US Law
}

\section{Mark R. Shulman*}

\section{INTRODUCTION}

It is a great honor to be here in this magnificent university in this lovely city serving on a panel with such learned colleagues. I must be brief both because all I can hope do is to amplify some of the wise comments that have already been presented and also because I realize that my comments keep you from your supper.

I am particularly delighted to be addressing the next cohort of Brazilian environmental lawyers. Protecting and preserving our shared environment is the critical issue that your generation faces. This morning Professor Tuiskon Dick proposed dealing with polluters by sending them into exile in Antarctica. Remember, he said, that in early 17th Century Europe, numerous laws mandated banishment for those who despoiled the environment. Those people who paid insufficient respect to the environment by tearing down fruit trees were to be sent to the African colonies or - if they were really terrible - to Brazil. Professor Dick continued, "What do we do now?" Where do we send people who do not treat the environment with the respect that it is due and who do not understand the implications for

Assistant Dean for Graduate Programs and Intemational Affiliations and Adjunct Professor, Pace Law School, White Plains, NY, USA. M Mark R. Shulnan, 2006. Please direct all comments or inquiries to him at MShulman@lawpace.edu.

The author thanks his gracious hosts Rector José Carlos Hennemann, Dean Sérgio José Porto and Professot Claudia linna Marques of the Federal University of Rio Grande do Sul and President David A. Caputo and Vice President Beverly Kahx of Pace University for the opportunity to present these remarks at the June 2005 conference on Globalizafäo Esonomita, Meio Ambiente e Snciedade Cinil / Eiconomic Glohatization, The Enmimment And Civil Society in honot of Prof. Dr. Tusskon Dick. He particularly thanks Professor Lima Marques and Vice President Kahn for their dedication to building collegial ties berween these two great educational instintions. He also thanks Professor Darren Rosenblum for his thoughtful comments on this chapter. 
the future generations? And he left us with this thetorical question. As this important day's work comes to a close, I will offer one suggestion of what to do with people. Rather than banish the despoilers, send them --. or at least their lawyers - to the United States for a year of advanced study.

After the wonderful experience that a budding lawyer receives here at the Federal University of Rio Grande do Sul, her education is more than half complete. Advanced study of comparative and environmental law in the United States would complement the lessons she learned here and ensure her readiness to practice in an increasingly globalized world. She will face a legal marketplace in which the Common Law system is increasingly influential, one in which the commercial and environmental issues require lawyers to practice across borders and legal systems. She would be well served to come to the United States and learn some of the complementary lessons we have learned through long experience, so she could compare them to the themes presented in today's symposium.

Accordingly, my task today is to explain what a Brazilian environmental lawyer could learn from sustained exposure to the US legal education system. I will briefly touch on five points about ( $i$ ) the role of dialogue; (it) the differences and distinctions between our systems; (iir) the U.S. legal systems and their relationship to international law; (iv) the impact of U.S. laws on a Brazilian's activities; and then (v) the opportunities that U.S. domestic law create for innovation. Each of these themes will echo the comments of the distinguished colleagues who spoke before me today. To provide a few useful insights of my own, I will draw heavily on my personal experience at Pace Law School.

\section{Dialogue}

First on dialogue. Lawyers are constantly striving ro communicate with each otherto express their clients' interests and to comprehend the other side. As Stanford Professor Barton $\mathrm{H}$. Thompson Jr. noted this afternoon, our ability to communicate effectively is the critical function of a lawyer and the key to making a difference. This is how we protect the environment that each man, woman and child should be able to enjoy. Only through a frank dialogue can we generate the optimal solutions to the varied and enormous challenges that we face.

At the risk of sounding chauvinistic, I believe that law schools and legal education play unique roles in establishing this sort of dialogue. Moreover, I believe that two educations are better than one. Significant exposure to another legal system is tremendously valuable in enabling cross-border dialogue. One's knowledge of the legal system in Btazil alone may prove insufficient for those seeking to negotiate, execute, or litigate a complex cross-border transaction. Though an expert in one jurisdiction, she may not have the tools required to master issues raised by cross-border matters. She will be limited in her ability to engage in meaningful and creative dialogue and to take full advantage of conversations such as those 
we are so privileged to enjoy today. For the sake of expanding her ability to participate in a true dialogue, for the sake of enabling her to communicate her clients' interests most successfully, it is important to experience another legal system, preferably one radically different from her own. 'To accomplish this, of course, she will generally be required to master an entirely different legal language, legal research and substantive law. Fortunately, many Brazilian lawyers go on for graduate degrees or doctoral degrees in European or North American universities and increasingly in South Asia and East Asia too. I am blessed to have studied in different countries and participated in forums like this on four continents over the past few years. Having had these opportunities to listen and leatn from lawyers atound the world, I think I become more capable lawyer and scholar. So the first lesson is that study of law in another country gives one powerful tools and insights into how to engage in constructive dialogue.

\section{Relevance of the Common Law}

The second lesson is that while the uniquely American ${ }^{1}$ Common Law system is not quite so exotic as civil law trained attomeys might think much is made of the distinction between Common Law systems and civil law systems. The former was derived over centuries of haphazard evolution, while the latter was drafted and enacted systemically. The former is articulated or revealed through formal, written and reasoned judicial opinions, the other by detailed and well-organized statutes. The former is highly localized, and the latter is more cosmopolitan in approach. Yes, these legal systems are different, and the distinctions are tremendously significant. Their divergent approaches to regulating human behavior dictate how we live our lives and the opportunities that we enjoy. All written constitutions follow the United States in time, but the drafters of each learned from their own civilizations and experience. They reflect their culture's tragedies and their successes. They have learned also from some of the mistakes that the United States made. In any case I think several notable issues arise in virtually every constitution. Just briefly, I would note three: the balance between liberty and equality; the tension between constituent regions (or states or provinces) and the nation; and the extent to which and the ways that popular democracy determines governmental policy:

1 With all due respect for citizens of other countries in the Americas, and for the sake of simplicity this essay uses the word "Ametican" as an adjective to indicate a person or institution of the United States of Amexica.

For an appreciation of this work, see 17ya Somin "Rehnquist's Federalist Legacy" (Sept. 13, 2005) https://www.cato.org/pub_display.phrpub_idw 4689. 


\section{LIBERTY v EQUALITY}

How does a constitution balance individual autonomy with equality? Compared to most, the United States Constitution tends to give priority to freedom over substantive equality. Liberté, equalité, fraternité: these are not the defining American principles. I respect these principles heartily, but they ate not articulated in the U.S. constitution which consistently gives priority to freedom over equality (let alone fraternity). Moreover, the form of equality that the U.S. Constitution does vigorously protect is an equality of opportunity and protection from state action seeking to diminish one's frecdom. Often, it is the way we strike this balance between liberty and equality that seems to define the American constitutional spirit. By studying how the U.S. weighs these values, one may corne to better understand how Brazil makes its own valuations.

\section{Federalism}

Second, it is important to understand that at the formation of our union we had thirteen independent autonomous and sovereign states that ceded power to a federal govemment. In some significant ways, the states of the European Union are atternpting to do the same - or at least were until the Danish voters rejected the draft constitution. As a pact anong sovereign states, U.S. Constitution is one of limited and expressively granted authority. "That was true in 1787 when the Founders wrote it. It was even more expressly true in 1791 when the United States adopted the first ten amendments to the Constitution (the Bill of Rights). The limitations on the federal government's authority waxed somewhat during the middle decades of the Twentieth Century as the nation faced the challenges posed by the Great Depression, the Second World War, and the Cold War. Restoring meaningful constitutional constraints on the federal government's ability to overrule or preempt the states was probably the principle objective of the Late Chief Justice William Rehnquist. ${ }^{2}$ But as Pace Professor David Cassuto noted in his etudite Jordon Young Lecture, the tide appears be turning on the growth to the federal authority. There is still no general federal authority. And since the 1995 Lopez case, the trend may be rerurning authority back to the states at the expense of the federal government's capacity to regulate in such important areas as environmental protection and gun control. ${ }^{4}$

2 For an apprectation of this work, see Iyya Somin "Rehnquist's Federalist Legacy" (Sept. 13, 2005) https:/ www cato.org/pub display.php?pub id=4689.

3 See David N. Cassuto, Jordan Young Lectuxe, published elsewhete in this volume.

4 See United States v. Loper 514 US 549 (1995) and for the trend away from this form of federalism, see Lindal Greenhouse, "The Rehnquist Court and Its Inperiled States' Rights Legacy" Nen York Times (June 12, 2005) http://wwwnytimes.com $/ 2005 / 06 / 12 /$ weekinreview $/ 12 \mathrm{green}$.htmlei=5090\&en=

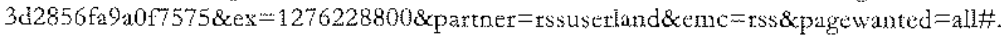


For those who are particularly interested in individual autonomy and freedom, the receding tide may be prove welcome in the face of the so-called "War on Terror" and its implications for the ahility of the government to subsume individual rights for the sake of homeland security. Such a change in positions would be archly ironic because of the roles increasing federal authority played in security individual rights during the Twentieth Century (for freedom of expression, reproductive rights, and equal rights for women and racial, ethnic and sexual minorities). Few Americans alive today can recall a time when states were seen as the best protection for indixidual liberties.

The "proper" balance between the states and the union is ultimately elusive and should continuously evolve with new social and technological situations. I would not hazard a guess as to where the United States will be a generation from now -w let alone the direction Brazil is going. But I do think that it is important to understand what this is principle of federalism means for Americans and the process by which we adjust. it. History tells us that changes in the US political and legal institutions are frequently copied by other states. Witness the wide-spread adoption of written constitutions and the subsequent embracing of fundamental rights in the Universal Declaration of Human Rights. In Brazil, of course, the balance is currently cutting the other way, but this sort of system is fluid as the U.S. experience teaches. So a Btazilian lawyer would be well-served by study of this evolution in the United States context.

\section{Republicanism v Democracy}

And finally the third principle that I think distinguishes United States legal order from representative forms of government is a distinct preference for a repuhlican form of government over that of popular democracy. The United States is the oldest continuously functioning democracy in the world (assuming that the United Kingdom did not become a democracy in any meaningful sense until the $19^{\text {th }}$ century). This is, however, a particular form of form of democracy that filters popular impulse through a variety of mechanisms designed to insulate the government, indeed to protect the elite, their property, and the discretion. It is in fact a republican political order. Among other things, this means that until the last century, our senators were not directly elected. They were elected by state legislators. And as much of the world learned late in the year 2000 , the President of the United States is not directly elected by the people. Instead, the people vote by state, and then the candidate with the most votes in a given statc receives the right to name electors who in turn are supposed to cast their ballots for him or her. ${ }^{5}$ Because of this arcane system, there have been several instances when the winning presidential candidate had not received the majority - or somctimes even the plutality - of the popular vote. 
Therefore, the United States enjoys a republican form of government. This is an important principle. It is an organizing principle for understanding how we govern ourselves, much like the Common I aw is a system of stare dicisis. In the U.S. legal system, interpretation of the law is guided and constrained by previous interpretations. In this way, the law is able to react to social, technological or political change gradually by reinterpreting the law at the margins. Stare decisis provides a mechanism by which society can change itself gtadually but peaceably, Likewise, the republican institutions moderate political change and thereby ensure enough continuity for the system to hold together. One sees that many of the elements that distinguish the U.S. system have also helped to enable it to endure longer and in many ways more stable than other forms of governments. At the same time, the U.S. Constitution is still one of the briefest in the world. Its seven articles have been amended only seventeen times since 1791 (iwo of which cancelled each other out).

One will find the Common Law system quite distinct from the system you have here in one additional and in significant ways that also allows U.S. law to constantly bend in order to accommodate to changed circumstances. Many of its standards are based on the actions of an unnamed and "reasonable man." How does one codify a reasonable man standard? And what about reasonable women, reasonable children or teasonable people of diminished capacity? This is an old standard it was adopted in the English courts in the 19th century, and we have bately adapted since then. The reasonable person standard is an important tool in the Comnon Law system - one uniquely suited to a system of judicial interpretation of the law.

The U.S. legal system offers some valuable comparative insights into ordeting a society. At the same time it can be most informative about the how (and how not to) affect international law.

\section{The US Legal System's UniQue ReLationship to INTERnationaL LAW}

The temperate effects of having a republican form of government, along with the flexibility afforded by a brief constitution and by the Common Law methods for adapting law to changed circumstances have afforded the American people a great deal of stability. Ironically, flexibility begets stability. In lighr of what I have just said, what is one to make of the fact that this reasonable man standard is increasingly incorporated into international law? How is that? Some of you are probahly familiar with the United Nations Convention on the International Sale of Goods (the "CISG)" adopted by sixty-seven nations since $1980 .{ }^{6}$

- For more on the United Nations Convention on the International Sale of Goods (1980) including the complete text as well as commentary, opinions and an extensive bibliography see http:// www.cisg.law.pace.edu/. 
The CISG is uniquely important to the regulation of commerce, particularly when something goes wtong. Who cares about a contract when everything goes right? When goods are destroyed or if the contract is somehow breached, then you have the Convention to look to. The CISG is a unique convention because its interpretation relies greatly and increasingly upon a Common Law style of interpretation. Not that the judges in Switzetland just take the word of U.S. judges, lawyers or academics on how to interpret the convention; of coutse not. Instead, lawyers from around the world must make atguments based on precedent. For many years, however, precedent was unavailable or available only in limited circles.

To address this short-coming we at Pace Law School have for several years collecting an internet database. Some of you will probably contribute to it. Pace's CISG database collects thousands over arbitral, judicial and academic interpretations of this key UN convention. These interpretations are used by administrators and judges to interpret the convention. These interpretations are essential precisely because they enjoy some form of value as controlling precedent - i.e. for common law style interpretation and use of what otherwise looks like a code. With the CISG database, lawyers around the world have equal opportunity to access the precedent upon which to base their arguments. It is an important tool for leveling the playing field. But the field would remain tilted if we did not also provide non-U.S. lawyers with the opportunity to develop the skills required to argue from precedent.

To fill the gap, Pace educates non-United States lawyers, both in its residential LL.M. program (a post-graduate one-year degree) and also through its Willem C. Vis International Commercial Moot. Every year in Vienna students from nearly 150 law schools around the world participate in a simulated arbitration in which they learn how to use American style Common Law interpretation to win their client's cases.? I will note there is a little irony in this because while this wonderful university (UFRGS) does send a team or even two teams each year, Brazil is not yet party of the convention. This university knows something that the federative republic does not.

Familiarity with the way American lawyers craft arguments based on precedent is uniquely helpful for non-United States lawyers with commercial enterprises for clients. On the public international law side $I$ think there are also examples where understanding how the United States systenz works will enable one to be more successful lawyers as she seeks to protect the environment, consumets, or yout client's other interests wherever they lay. Briefly we need to mention the Universal Declatation of Human Rights which adopted in $1948 .{ }^{8}$ Former United States first lady Eleanor Roosevelt (1884-1962) was the champion of this

' See Mark R. Shulman, "Moot Court Diplomacy" Interhutiont Herald Tribme (April 15, 2006) available at hatp:/ wwwiht.com/articles/2006/04/14/opinion/edshulmantphp.

8 Universal Declaration of Human Rights, adopted and proclaitned by General Assembly Resolution 217 A (III) (December 10, 1948). For more, see http://www unhchr.ch/udhr/. 
path breaking project, and many of the rights embodied in this declaration descend directly from the United States Bill of Rights (the first ten amendments) of the US Constitution and from interpretations of that Bill of Rights in the century and a half following its passage in 1791. For a lawyer to make a claim based on the Universal Declaration, therefore, one must understand not only the U.S. Constitution and its brilliant Bill of Rights hut also how courts have interpreted this constitution.

The second set of examples from public international law is the tribunals established at The Hague for prosecuting those accused of war crimes, genocide and crimes against humanity. These international tribunals - and now the International Criminal Court also established at The Hague - shate Common Law respect for precedent which has been developed particularly since 1995 by judges from various legal systems including socialist legal systems, the civil law traditions, the Common Law, and from mixed systems. The judges have recognized that in order to understand the crimes enumerated in their respective charters, the judges need to turn in elements of the crime ${ }^{\text {in }}$. Ptior to the establishment of these courts, the law governing these crimes was relatively inchoate ${ }^{11}$ and based on sporadic events over the centuries. So we are working with Common Law style of interpretation based on customaty international law that evolves from the practice of states and various treaties, each with contested meanings.

The U.S. style of making legal arguments should inform how one makes international law arguments. At the same time, U.S. substantial law may also affect one's clients in important ways.

\section{The Influence of US Law on Your Clients}

United States law has a significant impact on the ability of people around the world to engage in their own business. For this reason it is important to understand how to employ the Common Law system for the benefit of one's client, for her environment, for the consumers and for her fellow citizens. This is particularly true since September 11, 2001.

9 For biographical information, see http://wwwwhitehouse.gov/history/firstladies/ar32.html.

10 For more on the International Criminal Jribunals for the Former Yugostavia and Rwanda, see http:/ /wwww org/icty/ and htep://wwwun.org/ictr/. For the Intemational Criminal Court, see hitp:/ /wwwicc-cpi,int/home.html. For intetpretation and the significance of precedent, see the Rome Statute of the International Criminal Court, ast. $21 \$ 2$ (1998) ("The Court may apply principles and rules of law as incerpreted in its previous decisions.") avalable at http:/www un.org/law/icc/ statute $/ 99$ corr $/$ cstatute.htm.

For the International Criminal Court, see htp://wwwicc-cpi.int/home.html. For interptetation and the significance of precedent, see the Rome Statute of the International Criminal Court, art $21 \$ 2$ (1998) ("The Court may apply principles and rules of law as interpteted in its previous decisions.") available at http://www.un.otg/law/icc/statute/99_cort/cstatute.htrr.

11 See generally, Michais Howatr, George Andreopouzos anjo MLrk R. Shliman, Thr Laws of War (1994) 
The US Trading with the Enemy Act of 1917 has been in great part adopted by the United Nations Security Council Resolution 1373 passed in the wake of the attacks of September $11 .^{12}$ To understand how to comply with UN Security Council Resolution 1371 (passed not just by the Security Council but under the Chapter VII authority) it is a good idea to understand how the United States has been interpreting and enforcing laws about money laundering and fighting terrorism in general over the past century. Also the U.S. domestic legal system provides and encourages innovative solutions and engaging with our system may help lawyers in other countries to derive creative solutions, to create the responses for the enduring chronic problems that degtade the environment today. For instance, U.S. non-profit law, providing as it does the tax deductibility for donations ${ }^{13}$ and the powerful protection for freedom of association and expression afforded by the First Amendment $t^{14}$ foster a great variety of philanthropic institutions and organizations to grow and prosper, each creating new opportunities for civil society to meet ever-changing social challenges.

The complex interrelationship between the US and international law is also instructiveif imperfect. Over the past few years, the U.S. has quickly eroded its long-standing and welldeserved reputation for being respectful and supportive of international law. Ptior to September 11,2001 , the Bush Administration abandoned negotiations on START $I^{15}$, decided not to ratify the Comprehensive Test Ban Treaty ${ }^{16}$, and soon thereafter withdrew the United States from the Anti-Ballistic Missile Treaty ${ }^{17}$. It stalled efforts to improve the Biological Weapons Convention regine $^{18}$. It failed to encourage ratification of the U.N. Convention on the Law of the Sea, despite strong support in Congress, the Department of State, and the Department of Defense ${ }^{19}$. The Bush Administration took the unprecedented step of "un-signing" the 1998 Rome Chatter of the International Criminal Court. The Administration's antipathy to exposiag Americans to charges in international tribunals is so strong it expended considerable diplomatic capital to ensure blanket exemptions for Americans before the new International Criminal Court despite

i2 Ttading with the Enemy Act of 1917, 50 U.S.C.) et. seq.:

United Nations Security Council Resolution 1373, S/RES/1373 (September 28, 2001). See also http://www.un.org/sc/ctc/.

13 See 26 U.S.C. $\$ 501(\mathrm{c})(3)$.

is U.S. Conse. amend. I.

15 Michacl R. Gordon \& David E. Sanger, To Sway Russia, Bush IWill Proprase Culs to Nudear Arstnal, N.Y. Times, Noy. 2, 2001, at A6 (noting that Start II had still tiot taken effect).

16 Tom Shanker \& David E. Sanger, White House Wants to Bury Pact Banming Tests of Nuclear Arms, N.Y. Truss, Jul. 7, 2001, at. A1.

17 Maruel Perez-Rivas, U.S. Quits ABM Treat), ONN.Com, Dec, 14, 2001, http://atchives,cnn.com/2001/ ALIPOLITICS/12/13/tec.bush.abm/.

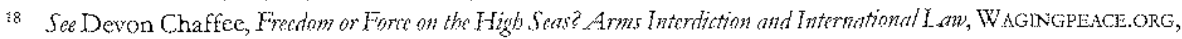
Aug. 15, 2003, http://www.wagingpeace.org/articles/2003/08/15_chaffee_freedom-of force.htm.

19 Marjorie A. Browne, Cong. Res. Serv, The U.N. Law of the Sea Convention and the United States: DEVEJOPMENTS SINCE OCTOBER 2003 (2005), antalable at http://wwwfas.org/sgp/crs/tow/RS21890.pdf (noting that though it had been voted favorably out of committee in the Senate and pushed by Department of State officials, it languished in the 108th Congress). 
the Rome Charter's provisions and political considerations making any such prosecution exceptionally unlikely. ${ }^{20}$ And yet many would argue that the US is so hesitant to enter into treaty obligations precisely because we take them so setiously. "They are, after all, the supreme law of the land. ${ }^{21}$ So the way the U.S. interptets international law affects the evolution and prospects for its success, much as the U.S. domestic law affects the patterns of law evolving elsewhere in the wotld.

\section{US DOMESTIC LAW AND INNOVATION}

So examining US domestic law will provide a young lawyer with more tools to serve her clients. I. ikewise the unique U.S. federalism system means that states and municipalities throughout the nation are each able to develop their own solutions to local problems. Through this experimentation, states and localities are able to serve as laboratories for change -..-much as states are in Btazil. Much of the most interesting experimentation takes place in the administration of real property by local governments. We at Pace Law School, therefore, created a Land Use Law Center in 1993 which takes the advantage of the fact that the State of New York has ceded to Westchester County and to the City of White Plains, a great deal of authority to determine how land is best used. "The Land Use Law Center is dedicated to fostering the development of sustainahle communities in New York State. Through its many programs, the Center offers lawyers, land use professionals, citizens and developers assistance that enables them to achieve sustainable development at the local and regional level.".2 The Center's staff has collected the learning of many communities to cteate the innovative Gaining Ground Information Database. ${ }^{23}$ Pace Law students conduct research on cutting-edge land use topics. More than sixty student papers have been produced under this program, many of which have been published in prestigious law reviews and journals. To put this learning to good effect, the Iand Use Law Center brings developers together environmental activists and local governing officials to try to come up with creative solutions that will allow for development in a sustainable way.

\section{CONCLUSION}

In conclusion I would claim that the Common Law as taught by the U.S. legal system in particular provides highly complementary and useful insights and tools for those working to preserve the environment whether locally, nationally or internationally. Come see for yourself!

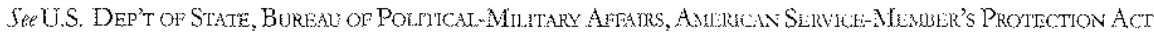
(2003), aluililly at http://wwwstate.gov $/ \mathrm{t} / \mathrm{pm} / \mathrm{rls} / \mathrm{othr} / \mathrm{misc} / 23425 \mathrm{ktm}$. All this is in addition to the protections embodied both in the U.S.'s veto at the Security Council and the Rome Charter's prowisions for complementarity, that is authorization for indictments only when the state does not have the capacity to indict or investigate. "The Rome Statute emphasizes "the International Criminal Court established under this Statute shall be complementary to national criminal jurisdictions." Rome Stutute of the International Ctiminal Court, Pmbl., JuIy 17, 1998, UN, Doc. A/CONJ183/9, alizilable at hatp://www un.otg/law/icc/statute/romefrathtm.

See http://wwwilawpace.edu/landuse/

23 See http://Landuse, lawpace.edu/. 